\title{
GŁÓWNE DETERMINANTY POLITYKI BEZPIECZEŃSTWA NARODOWEGO REPUBLIKI CHORWACJI W LATACH 1995-2013*
}

\author{
JĘDRZEJ PASZKIEWICZ
}

\begin{abstract}
Jędrzej Paszkiewicz, Główne determinanty polityki bezpieczeństwa narodowego Republiki Chorwacji w latach 1995-2013 (Main determinants of Croatian national security policy during the 1995-2013 period).

Balcanica Posnaniensia. Acta et studia, XX, Poznań 2013, Wydawnictwo Instytutu Historii UAM, pp. 217-227, ISBN 978-83-63047-36-1, ISSN 0239-4278. Polish text with a summary in English.

Jędrzej Paszkiewicz, Uniwersytet im. Adama Mickiewicza, Instytut Historii, ul. Św. Marcin 78, 61-809 Poznań.
\end{abstract}

Analiza ewolucji polityki bezpieczeństwa Republiki Chorwacji wymaga uwzględnienia złożoności warunków w jakich państwo to rozwijało się od początku lat dziewięćdziesiątych XX wieku. Jego struktury były tworzone w warunkach konfliktu zbrojnego o charakterze wewnętrznym i międzynarodowym. Walki były rezultatem wielopłaszczyznowych antagonizmów między niezależnymi państwami powstałymi na gruzach socjalistycznej Jugosławii. Konfrontacja wojenna korespondowała z nieodwracalnym rozpadem jugosłowiańskich struktur społeczno-politycznych. Wywarła decydujący wpływ na podejście władz i społeczeństwa chorwackiego do spraw bezpieczeństwa w kraju i w całym rejonie postjugosłowiańskim.

Ewolucja polityki bezpieczeństwa Republiki Chorwacji zazwyczaj jest ujmowana w trzech etapach, odpowiadających przemianom społeczno-politycznym w państwie. Pierwszy etap dotyczy lat 1990-1995. Jest to czas krwawego konfliktu wojennego na terytorium Chorwacji oraz Bośni i Hercegowiny. Drugi etap obejmuje lata 1995-2000, gdy najważniejszymi celami były konsolidacja terytorium państwa i odbudowa ze zniszczeń wojennych. Dominującą pozycję w instytucjach państwowych utrzymała wówczas Chorwacka Wspólnota Demokratyczna (Hrvatska demokratska zajednica; HDZ), utożsamiana z niepodległościowymi aspiracjami narodu chorwac-

* Niniejszy tekst został złożony do druku pod koniec 2013 roku, gdy nierozstrzygnięte były losy projektu strategii bezpieczeństwa narodowego Republiki Chorwacji, przygotowywanej przez władze Republiki Chorwacji od końca 2010 roku. 
kiego ${ }^{1}$. Z kolei trzeci etap, którego początkową cezurę stanowi 2000 rok, jest utożsamiany z natężeniem działań różnych orientacji politycznych ku implementacji standardów obowiązujących w Pakcie Północnoatlantyckim (NATO) i Unii Europejskiej (UE) w zakresie polityki bezpieczeństwa ${ }^{2}$. Zmiany prawne i organizacyjne, dotyczące zgrania koncepcji bezpieczeństwa Republiki Chorwacji z oczekiwaniami obu organizacji są w toku, choć formalnie państwo chorwackie jest już członkiem struktur euroatlantyckich, od 2009 NATO, a od lipca 2013 roku UE.

W okresie 1990-1995 kwestię bezpieczeństwa Chorwacji ujmowano przez pryzmat działań zmierzających do odzyskania kontroli wojskowej i politycznej nad terenami kontrolowanymi przez separatystyczną Serbską Republikę Krainy. Na pierwszy plan wysuwały się wówczas działania w kierunku utwierdzenia integralności terytorialnej państwa i określenia jego granic w warunkach płynnej sytuacji w rejonie postjugosłowiańskim. Od 1995 roku szczególnego znaczenia nabierają zabiegi na rzecz politycznej i ekonomicznej reintegracji obszaru walk z resztą Republiki, wraz z działaniami zmierzającymi do stabilizacji stosunków społecznych, politycznych i ekonomicznych ${ }^{3}$.

Ze względu na to, że tworzenie struktur państwowych Republiki Chorwacji odbywało się $\mathrm{w}$ realiach krwawego konfliktu etnicznego, transformację systemową w wydaniu chorwackim trudno porównywać do doświadczeń państw Europy środkowo-wschodniej o zbliżonej metryce. Czechy, Słowacja, Litwa, Łotwa i Estonia podejmowały trud zmian systemowych w kierunku ustroju demokratycznego, opartego na gospodarce rynkowej w warunkach pokoju wewnętrznego i zewnętrznego. Dzięki śmiałym reformom państwa te w ciągu jednej dekady poczyniły postępy na drodze ku strukturom euroatlantyckim ${ }^{4}$. W przypadku Chorwacji ten proces się wydłużył. Na ten stan rzeczy wpłynęły chwiejna sytuacja międzynarodowa w rejonie postjugosłowiańskim oraz niekorzystne tendencje obserwowane w polityce wewnętrznej. W drugiej połowie lat dziewięćdziesiątych w chorwackiej praktyce społeczno-politycznej podkreślana była konieczność utrzymania mobilizacji narodowej społeczeństwa wobec wszelkich przejawów zagrożenia państwa. Stanowisko to przekładało się na niechętny stosunek władz wobec mniejszości etniczno-narodowych i działań promujących dialog z państwami regionu. Rządząca HDZ dystansowała się wobec koncepcji współpracy regionalnej, choć zdawano sobie sprawę, że był to warunek sine qua non rozpoczęcia rozmów o członkostwie w NATO i UE. Ta ówczesna rezerwa Chorwacji wobec środowiska międzynarodowego korespondowała z krytycznym stanowiskiem zagranicy. Władzom chorwackim zarzucano łamanie wolności słowa, upolitycznie-

${ }^{1}$ L. J. Cohen, Embattled democracy: postcommunist Croatia in transition, w: Politics, power, and the struggle for democracy in South-East Europe, red. K. Dawisha, B. Parrto, Cambridge 1997, s. 103.

2 S. Knezović, Z. Mahečić, Hrvatska, w: Almanah o nadzoru sektora bezbednosti, Beograd 2012, s. 74-75.

3 L. J. Cohen, Embattled democracy..., s. 103-106.

${ }^{4}$ Z. Dizdarević, Upitna budućnost regije nakon ulaska Hrvatske u EU, w: Politike evropskih integracja, red. M. Grünther Đečević, N. Mujagić, Sarajevo 2012, s. 72; D. Grubiša, The Europeanization of Croatia's security discourse, „Politička misao”, t. XLVI, nr 5, 2009, s. 42-43. 
nie aparatu państwowego, utwierdzanie kryminogennych powiązań między polityką a biznesem ${ }^{5}$. W chorwackiej literaturze naukowej okres ten przyjęło się nazywać czasem „deficytu demokracji”, gdy środowisko związane z HDZ przejęło kontrolę nad instytucjami państwa, wykorzystując je do utwierdzenia swojej przewagi wobec opozycji ${ }^{6}$. Służby bezpieczeństwa były przez rządzących uznawane za narzędzie realizacji celów partyjnych lub interesów poszczególnych decydentów ${ }^{7}$. Instrumentalizacja aparatu bezpieczeństwa w rękach rządzących była możliwa wskutek podporządkowania go urzędowi prezydenta, za przyzwoleniem bezwolnego rządu i przy biernym parlamencie, zdominowanym przez $\mathrm{HDZ}^{8}$.

Zmiana tego stanu rzeczy okazała się możliwa dopiero po śmierci pierwszego prezydenta Republiki Chorwacji Franjo Tudjmana w grudniu 1999 roku. Zniknięcie ze sceny politycznej postaci uznawanej przez wielu Chorwatów za ojca państwowości chorwackiej ukazało słabość HDZ i uzewnętrzniło niezadowolenie społeczeństwa $\mathrm{z}$ dotychczasowych rządów. Wybory parlamentarne, przeprowadzone w styczniu 2000 roku pokazały, że w życiu społeczno-politycznym zaistniały warunki umożliwiające zmianę podejścia rządzących do spraw państwowych. Głównym celem sił centrolewicowych, które wówczas przejęły władzę było wprowadzenie rozwiązań dających legislatywie większy wpływ na kwestie bezpieczeństwa i obronności kraju. Zamysłem reformy była reorganizacja wszystkich instytucji bezpieczeństwa pod kątem ich profesjonalizacji i uniezależnienia od wpływów politycznych. Postulat umocnienia praworządnej kontroli nad sektorem bezpieczeństwa był postrzegany jako

5 S. Knezović, Z. Mahečić, Hrvatska..., s. 76; por. D. Jović, Ch. Lamont, Croatia after Tuđman: encounters with the consequences of conflict and authoritarianism, „Europe-Asia studies”, t. LXII, 2010, nr 10, s. 1612-1614.

6 Por. D. Lalović, O totalitarnim značajkama hrvatske države (1990.-1999.), „Politička misao”, t. XXXVII, 2000, nr 1, s. 188-204.

7 V. Cvrtila, Intelligence governance in Croatia, Geneva 2012, s. 9; http://dcaf.ch/Publications/CaseStudies-on-Intelligence-Governance-in-the-Western-Balkans [dostęp: 18 X 2013].

8 W latach 1991-1993 działało Biuro Ochrony Porzqdku Konstytucyjnego (Ured za zaštitu ustavnog poretka; UZUP), powołane na mocy dekretu prezydenta. Było ono odpowiedzialne za koordynację działań wszystkich instytucji odpowiedzialnych za bezpieczeństwo państwa. W praktyce traktowano je jako organ o charakterze kierowniczym. W marcu 1993 roku kompetencje biura przejęła Rada ds. bezpieczeństwa narodowego (Ured za nacionalnu sigurnost; UNS). Prawne podstawy dla jej działalności zawarto w ustawie uchwalonej przez Sabor w maju 1995 roku. W składającym się z 17 artykułów akcie sprecyzowano system organów bezpieczeństwa bezpośrednio podległych urzędowi. Były to służba wywiadowcza (Hrvatska izvještajna služba; HIS), Kwatera Główna Bezpieczeństwa (Stožer osiguranja) i Stużba Kontrolna (Nadzorna služba). Ponadto powołano Narodowe Centrum Monitoringu Elektronicznego (Nacionalna služba elektroničkog izviđanja; NSEI) i Akademię Wywiadu (Obavještajna akademija). Przewodniczący urzędu, powoływany przez prezydenta, odpowiadał przed głową państwa za działalność wszystkich podległych mu służb. Za koordynację prac ministerstw w zakresie bezpieczeństwa państwa odpowiadały Naczelny Komitet Bezpieczeństwa Narodowego (Stožerni odbor nacionalne sigurnosti; SONS) i Komitet Koordynacyjny Stużb Wywiadu (Koordinacijski odbor obavještajne zajednice; KOOZ). Oprócz Chorwackiej Stużby Wywiadu (HIS) w ramach struktur wywiadowczych działały Stużba Ochrony Porzqdku Konstytucyjnego (Služba za zaštitu ustavnog poretka; SZUP) oraz Stużba Bezpieczeństwa i Wywiadu Ministerstwa Obrony (Sigurnosno-informativna služba, SIS). Wszystkie służby podporządkowano ośrodkowi prezydenckiemu; ibidem, s. 6-8. 
integralny element transformacji całego systemu państwowego. Reformę sektora bezpieczeństwa uznawano również jako warunek sine qua non umocnienia systemu demokratycznych rządów prawa, ochrony praw człowieka i pokojowego rozwiązywania sporów kompetencyjnych w państwie?

Pierwszym krokiem w tym kierunku było umocnienie roli Saboru. Osłabiono pozycję konstytucyjną prezydenta a podlegające mu agendy silniej podporządkowano rządowi lub parlamentowi. Na mocy zmienionego w 2000 roku artykułu 102 konstytucji Republiki Chorwacji Sabor zyskał prawo opiniowania wyboru kandydatów na szefów służb bezpieczeństwa narodowego. Osłabiono wpływ środowiska generalskiego, wzmacniając mechanizm cywilnej kontroli nad siłami zbrojnymi za pośrednictwem ministerstwa obrony i komisji parlamentarnych. Ponadto podjęto pracę nad ustaleniem całościowej, długofalowej doktryny bezpieczeństwa Republiki Chorwacji, określanej mianem strategii bezpieczeństwa narodowego ${ }^{10}$.

Zmiany w kierunku większej demokratyzacji porządku prawno-politycznego zaowocowały zbliżeniem państwa chorwackiego do struktur euroatlantyckich. Jeszcze w 2000 roku Chorwacja przyłączyła się do natowskiego programu Partnerstwo dla Pokoju, a w 2001 do Paktu Stabilności dla Europy Południowo-Wschodniej, nadzorowanego przez Unię Europejską. W okresie tym rządzący stanęli przed koniecznością określenia celów bezpieczeństwa państwa, uzasadniających jego obecność w strukturach promujących współpracę międzynarodową w zakresie ładu, bezpieczeństwa i stabilizacji w Europie. Postanowiono jak najszybciej opracować pakiet tzw. dokumentów strategicznych na czele ze wspomnianą strategią bezpieczeństwa narodowego. Rządzący uważali, że pod tym względem Chorwacja znajdowała się daleko w tyle za państwami Europy środkowo-wschodniej. Ponadto władzom zależało na pokazaniu światu, że są wiarygodnym partnerem w relacjach międzynarodowych, wspierają rozwiązania pokojowe i długofalową, wielostronną współpracę w regionie ${ }^{11}$. Równie istotne było przekonanie sojuszników, że chorwackie elity polityczne i wojskowe są w stanie zmienić zdystansowane stanowisko wobec sąsiadów. Dodajmy, że w latach dziewięćdziesiątych decydenci powiązani z rządzącą HDZ z niechęcią myśleli o przyjęciu strategii bezpieczeństwa narodowego. Uważano, że uchwalenie takiego aktu nie zapewni logicznej polityki bezpieczeństwa. Przeciwnie, mogłoby wręcz zagrozić bezpieczeństwu Republiki w realiach dynamicznie zmieniających się konfiguracji geopolitycznych na Bałkanach. Podkreślano wówczas konieczność bieżącego modelowania działań w tej dziedzinie przez odpowiednio przygotowanych specjalistów, działają-

\footnotetext{
${ }^{9}$ S. Kušić, Croatia: advancing political and economic transformation, „Southeast European and Black Sea Studies", t. VI, 2006, nr 1, s. 65-66.

${ }^{10}$ Razvoj civilnog društva u Hrvatskoj (Program Ujedinjenih naroda za razvoj u Hrvatskoj), Zagreb [b.d.], s. 15-17.

${ }^{11} \mathrm{~W} 2000$ roku w zagranicznych komentarzach prasowych akcentowano, że wielkim wyzwaniem dla środowiska politycznego, które doszło wówczas do władzy w Chorwacji była zmiana jej negatywnego wizerunku na arenie międzynarodowej. Chorwację postrzegano jako państwo wpływające na destabilizację politycznej w rejonie postjugosłowiańskim; por. Post-Tudjman Croatia. The rocky road to reform, „Strategic Comments” t. VI, 2000, nr 3, s. 1-2.
} 
cych w ramach sektora bezpieczeństwa. Myśl o oddaniu tej kwestii parlamentowi budziła również opór kół wojskowych, które obawiały się ograniczenia swojej roli w kontroli sił zbrojnych. Dodajmy, że zmarły w 1999 roku prezydent Franjo Tudjman był zdania, że sprawy bezpieczeństwa państwa należało określać w praktyce, ponieważ wykraczają one poza sferę sztywnych przepisów. Kilkakrotnie odrzucił on projekty strategii, uważając, że miały one na celu ograniczenie jego uprawnień w sferze kontroli nad siłami zbrojnymi i służbami bezpieczeństwa. $\mathrm{Z}$ tego względu efektywne prace nad strategią okazały się możliwe dopiero po śmierci F. Tudjmana i osłabieniu pozycji HDZ.

Harmonogram działań w tej sprawie ujęto w rządowym planie legislacyjnym na lata 2000-2003 o nazwie Chorwacja w XXI wieku. Pierwotnie zakładano, że zarys dokumentu powstanie w ramach zespołu specjalistów, działającego pod auspicjami ministerstwa obrony. Instytucje państwowe - ministerstwa i agencje - miały wspomagać działalność zespołu, zadbać o jego obsługę prawną i organizacyjną. Oczekiwano, że przyjęcie takiej strategii postępowania odświeży spojrzenie na sprawy bezpieczeństwa kraju, osłabi wpływ establishmentu polityczno-wojskowego na kształt nowej filozofii rządzenia. Nie zdołano jednak przezwyciężyć sprzeciwu części decydentów wobec wniosków wypracowanych przez specjalistów. Zastrzeżenia zgłaszali przedstawiciele służb specjalnych, sztabu generalnego i samo ministerstwo obrony. W rezultacie po półtorarocznej działalności zespołu rząd ogłosił wycofanie się ze wszystkich ustaleń. Koncepcje wypracowane przez gremium eksperckie odłożono na półkę, a kluczowe dla bezpieczeństwa narodowego dokumenty, Narodową Strategię Bezpieczeństwa i ustawę o obronie państwa, zwaną także Strategią Obrony przygotowało w ciagu niespełna kilku tygodni sześcioosobowe grono urzędników rządowych i wojskowych $^{12}$. W strategii bezpieczeństwa zaakcentowano priorytetowe znaczenie integracji ze strukturami euroatlantyckimi, określając ją mianem jednego z najważniejszych celów narodowych. Ponadto wszystkie państwa sąsiednie, łącznie z Jugosławią, zostały uznane za partnerów w działaniach na rzecz rozwoju i stabilizacji regionu ${ }^{13}$.

$\mathrm{Na}$ Strategię bezpieczeństwa narodowego złożyło się 97 punktów, które ujęto w sześć zasadniczych części. W pierwszych dwóch rozdziałach scharakteryzowano najbliższe środowisko bezpieczeństwa Chorwacji (I.) i sprecyzowano interesy narodowe, realizowane przez to państwo ( II.). Część trzecią strategii poświęcono rzeczywistym i potencjalnym zagrożeniom. Spośród zagrożeń zewnętrznych wymieniono możliwość wystąpienia „konfliktów zbrojnych o mniejszej intensywności” w pobliżu Chorwacji i kryzysy z innych części świata, mogące wpływać na sytuację polityczną oraz ekonomiczną państwa. Zagrożenia wewnętrzne zdefiniowano w kontekście negatywnych następstw transformacji systemowej (problemy ekonomiczne, korupcja, bezrobocie), opieszałości sądownictwa, zmniejszania się liczby ludności i kontro-

12 S. Knezović, Z. Mahečić, Hrvatska ... op. cit., s. 77-78.

13 Strategija narodne sigurnosti RH, „Narodne novine”, 32/2002; Zakon o obrani RH, „Narodne novine", 33/2002; I. Tabak, Jedan pogled na buduću Strategiju nacionalne sigurnosti (SNS), w: Sigurnost: od koga, za koga. Prilozi diskusiji o sigurnosnoj politici RH, red. V. Horvat, Zagreb 2009, s. 49-50. 
wersji wokół praw dla mniejszości narodowych. Wspomniano o niebezpieczeństwie globalnego terroryzmu, przestępczości zorganizowanej, uchodźstwa, o zagrożeniu katastrofami naturalnymi (ekologicznymi) i technologicznymi (w tym również informatycznymi). Ponadto zwrócono uwagę na ciągle istniejące w Chorwacji zagrożenie minami, będącymi pozostałością po wojnie z lat dziewięćdziesiątych. W części czwartej strategii sprecyzowano cele polityki bezpieczeństwa, akcentując konieczność wspomagania rozwoju społeczno-politycznego i ekonomicznego społeczeństwa chorwackiego oraz porozumienia z innymi państwami demokratycznymi. Spośród instrumentów polityki bezpieczeństwa, zawartych w części czwartej strategii, wymieniono stabilizację stosunków z państwami sąsiednimi, rozwijanie współpracy regionalnej i współdziałanie w różnych dziedzinach z organizacjami międzynarodowymi.

Parlament przyjął strategię bezpieczeństwa i strategię obrony w tym samym dniu, 19 marca 2002 roku $^{14}$. Dokładnie rok później prezydent Republiki podpisał ustawę o służbie wojskowej, popularnie określaną mianem Strategii Wojskowej ${ }^{15}$. Krytycy szybko zwrócili uwagę na problemy z ustaleniem odniesień między tymi aktami. Podkreślano, że pokrywają się one w takich sprawach, jak obrona granic czy koncepcja sił zbrojnych, osłabiając rangę Strategii Bezpieczeństwa Narodowego mającej być główną wykładnią chorwackiego bezpieczeństwa narodowego. Problemy interpretacyjne pogłębiły się w kolejnych latach. We wrześniu 2005 roku rząd przyjął „Strategiczny Przegląd Obrony” (,Strateški pregled obrane”), w którym zawarto analizę celów strategicznych i potencjalnych zagrożeń wojskowych. Dokument nie został jednak odniesiony do istniejącego systemu prawnego. Nie zdefiniowano jego miejsca w hierarchii aktów strategicznych, nie określono która z instytucji państwowych powinna wdrażać przyjęte zalecenia. Przedstawiciele ministerstwa obrony żywili przekonanie, że tego typu akt po prostu powinien zaistnieć w chorwackiej praktyce, tak jak w praktyce amerykańskiej funkcjonuje publikowany co cztery lata „Quadrennial Defence Review". Wbrew powyższemu wzorcowi kolejny chorwacki przegląd obrony ujrzał światło dzienne dopiero po siedmiu latach. Dodajmy, że przystapieniu

${ }^{14}$ Dwa dni po przegłosowaniu Strategii Bezpieczeństwa Narodowego, 21 marca 2002 r., Sabor przyjął ustawę o służbach bezpieczeństwa (Zakon o sigurnosnim službama Republike Hrvatske). Na podstawie dotychczasowego systemu stworzono trzy agencje wywiadu: wywiadowczą (Obavještajna agencija; OA, dawniej HIS), kontrwywiadu (Protuobavještajna agencija; POA, dawniej SZUP) i wywiadu wojskowego (Vojna sigurnosna agencija; VSA, dawniej SIS). Centralnym organem kierującym i nadzorującym sprawami bezpieczeństwa narodowego stała się Rada Bezpieczeństwa Narodowego (Vijeće za nacionalnu sigurnost). W jej składzie zasiadają m.in. prezydent, ministrowie resortów strategicznych, szefowie agencji, szef sztabu generalnego sił zbrojnych, przewodniczący Saboru). Ponadto powołano Radę ds. Koordynacji Stużb Bezpieczeństwa i Wywiadu (Savjet za koordinaciju sigurnosnih službi) wraz z instytucją pomocniczą, Biurem Narodowej Rady Bezpieczeństwa (Ured Vijeća za nacionalnu sigurnost). W związku z licznymi sporami politycznymi i personalnymi w sprawie obsady stanowisk w służbach wywiadu, w połowie 2006 roku parlament przyjął ustawę o systemie bezpieczeństwa i wywiadu (Zakon o sigurnosno-obavještajnom sustavu; „Narodne novine”, 79/2006). Agencje wywiadu i kontrwywiadu połączono wówczas w jedną instytucję (Sigurnosno-obavještajna agencija, SOA) a agencję wywiadu wojskowego przekształcono w Agencję Bezpieczeństwa i Wywiadu Wojskowego (Vojna sigurnosno-obavještajna agencija, VSOA), z kompetencjami dotyczącymi działalności poza granicami kraju; V. Cvrtila, op. cit., s. 11-12.

${ }^{15}$ Zakon o službi u Oružanim snagama Republike Hrvatske, „Narodne novine”, 33/2002. 
Chorwacji do NATO nie towarzyszyło przyjęcie żadnych oficjalnych raportów podsumowujących stan reformy sektora bezpieczeństwa ${ }^{16}$.

Strategia z 2002 roku jest krytykowana z różnych powodów. Zdaniem znawcy prawa międzynarodowego Damira Grubišy opiera się ona na zbyt tradycyjnym podejściu do spraw bezpieczeństwa, bazującym na czynnikach militarnych i politycznych. Jej słabością jest niedostateczne powiązanie bezpieczeństwa państwa z bezpieczeństwem jednostki i obywatela. W strategii niewystarczająco określono rolę państwa jako podmiotu zabezpieczającego indywidualne prawa obywateli w wymiarze politycznym, kulturowym i ekonomicznym. Za mało jest o roli bezpieczeństwa kooperatywnego, które wymaga od państwa aktywności międzynarodowej w kierunku ograniczenia bądź likwidacji różnorodnych zagrożeń ${ }^{17}$. Jak podkreślił D. Grubiša, od chorwackich elit należy oczekiwać, by w kolejnej strategii zdobyły się na przyjęcie takiej formuly bezpieczeństwa narodowego, która bardziej otworzy państwo na sprawy obywateli i wyjdzie poza wąsko pojętą geopolitykę. Należy przezwyciężyć lęk przed współpracą, obalić traumatyczne doświadczenia wojenne i osłabić znaczenie sentymentu nacjonalistycznego w podejściu do spraw bezpieczeństwa regionalnego - uważa Damir Grubiša ${ }^{18}$.

Władzom zarzucano, że nie dopuściły do prac nad strategią przedstawicieli organizacji pozarządowych. Trzeba przyznać, że zaangażowanie tych środowisk, istotne dla uwzględnienia opinii, interesów społeczeństwa w projekcie dokumentu było utrudnione. Ówczesne organizacje pozarządowe w Chorwacji były rozproszone i stosukowo nieliczne. $Z$ drugiej strony rządzący nie chcieli sięgać po to rozwiązanie. Obawiali się, że spowolni ono proces przygotowania strategii. Ponadto oceniano, że czesść organizacji miała niejasne powiązania biznesowe i sympatyzowała ze stanowiskiem opozycji, krytykującej poczynania władz. Nie inaczej podchodzono do kontaktów z organizacjami międzynarodowymi. Choć każda opinia z zewnątrz była z uwagą analizowana przez komisję pracującą nad strategią, nie włączono nikogo spoza struktur rządowych. Władze uważały, że należało się oprzeć na miejscowych specjalistach, współpracujących z rządem i wojskiem. Chodziło o pokazanie społeczeństwu, że strategia powstała bez żadnych nacisków z zewnątrz. $Z$ drugiej strony nie zadbano jednak o językową przystępność dokumentu. Zastosowany w niej specjalistyczny żargon zniechęcał obywateli do studiowania zasad nowej polityki bezpieczeństwa, utrudnił popularyzację tematu wśród opinii publicznej ${ }^{19}$.

Krytyka strategii z 2002 roku dotyczy również złej polityki informacyjnej na jej temat. Media nie miały wystarczającej wiedzy o koncepcjach wypracowanych podczas zamkniętych posiedzeń eksperckich i rządowych. Opinia publiczna w zasadzie

16 Kolejny Strategiczny Przegląd Obrony rząd opracował pod koniec lipca 2013 roku na podstawie nowej ustawy o obronie, przyjętej przez Sabor 14 czerwca 2013 roku; http://obris.org/dokumenti/ [dostęp: 17 X 2013].

${ }^{17}$ D. Grubiša, The Europeanization of Croatia's security discourse..., s. 47-48.

18 Ibidem, s. 51.

${ }^{19}$ Z. Mahečić, Security policies in the Western Balkans: Croatia, w: Security policies in the Western Balkans, red. M. Hadžić, M. Timotić, P. Petrović, Belgrade 2010, s. 63. 
nie była informowana o założeniach strategii, zmianach z postrzeganiu bezpieczeństwa państwa, nowo tworzonych strukturach. Redakcje faworyzowały poszczególne opcje polityczne, filtrując informacje w oparciu o sprawy najbardziej absorbujące odbiorców. Z pewnością zabrakło specjalistycznych źródeł informacji w postaci urzędowego periodyku o sprawach bezpieczeństwa i obrony. Sytuacja ta częściowo wynikała ze stanowiska chorwackich sfer politycznych. Uważano że propagowanie informacji o pracach nad reformą polityki bezpieczeństwa wśród obywateli mogło opóźnić proces dochodzenia do ostatecznych decyzji i narazić go na presję ze strony środowisk bezpośrednio nie zaangażowanych $\mathrm{w}$ przygotowania ${ }^{20}$. W rezultacie dokumenty strategiczne przygotowano w błyskawicznym tempie, bez należytego poinformowania społeczeństwa o zasadach reformy systemu bezpieczeństwa. Sabor bezzwłocznie przegłosował ich przyjęcie.

Mimo omówionych powyżej zarzutów pod adresem transparentności trybu opracowania, strategia bezpieczeństwa narodowego z 2002 roku została jednak uznana przez obserwatorów jako sygnał postępującej normalizacji w polityce bezpieczeństwa Republiki Chorwacji ${ }^{21}$. Uznano, że w okolicznościach ówczesnego przełomu politycznego trudno było przygotować dokument o innym wydźwięku. Mimo tych ograniczeń państwo chorwackie dokonało dużego skoku w kierunku przezwyciężenia dekady, gdy sprawami bezpieczeństwa rządzący uzasadniali działania wymierzone w wolności obywatelskie. Głównym problemem strategii było jednak to, że tuż po jej przyjęciu zaczęła się ona „starzećc ze względu na szybkie zmiany polityczne w kraju i zagranicą. Jeszcze w połowie 2006 roku w dokumencie figurowała Federalna Republika Jugosławia, rozwiązana w 2003 roku. Strategia nie wspomina też nic o Kosowie, choć od 2008 roku Chorwacja utrzymuje z nim stosunki dyplomatyczne. Nie uwzględniono w niej również wejścia Chorwacji do NATO ${ }^{22}$.

Co ciekawe proces przygotowania nowej strategii bezpieczeństwa stanowi nie lada wyzwanie dla chorwackich elit politycznych. Pierwotnie zapowiadano, że nowy dokument będzie gotowy za rządu HDZ w latach 2003-2007, a więc jeszcze na etapie rozmów członkowskich z NATO. Zasadnicze prace podjęto jednak dopiero na początku 2009 roku. Tylko w ciagu czterech lat powołano dwie komisje do spraw opracownia strategii. Pierwsza, działająca pod kuratelą ministerstwa obrony przedstawiła projekt ustawy w połowie grudnia 2010 roku. Rada Bezpieczeństwa Narodowego

${ }^{20} \mathrm{Z}$ drugiej strony w proces tworzenia dokumentów strategicznych w sposób nieporównywalnie większy niż w przeszłości zaangażowane były środowiska naukowe. Argument ten prawdopodobnie przesądził niestety o unieważnieniu w finalnej fazie rozmów, większości decyzji podjętych przez niezależny zespół ekspertów. Część naukowców, niezadowolonych z rezultatu prac przypuściła atak na fachowców zaangażowanych w ten proces, korzystając ze wsparcia struktur wojskowych i urzędniczych; I. Tabak, Jedan pogled na buduć Strategiju nacionalne sigurnosti (SNS), w: Sigurnost: od koga, za koga... op. cit., s. $49-50$.

${ }^{21}$ Por. D. Grubiša, Nacionalna sigurnost Hrvatske,državo-centrizam i koncepcija ljudske sigurnosti, w: Sigurnost: od koga, za koga... op. cit., s. 97.

${ }^{22}$ Rozwinięciem regulacji na temat terroryzmu, zawartych w strategii bezpieczeństwa jest przyjęta przez rząd 27 XI 2008 roku narodowa strategia zapobiegania i zwalczania terroryzmu; „Narodne novine", 139/2008. 
przekazała go do miesięcznych konsultacji społecznych. Władze zapowiadały nagłośnienie dyskusji, nosiły się z zamiarem zaaranżowania ogólnonarodowego „okrąłego stołu“ na temat dokumentu ${ }^{23}$. Skończyło się jednak na pięciu spotkaniach-konferencjach z dziennikarzami (23 grudnia 2010), przedstawicielami organizacji kombatanckich (11 stycznia 2011), działaczami organizacji pozarządowych (14 i 20 stycznia 2011) i naukowcami (25 stycznia 2011). Projekt wrócił do komisji po czym został odłożony ad acta i nigdy nie trafił pod obrady Saboru. W prasie spekulowano, czy o fiasku prac komisji nie zadecydował sprzeciw „starej gwardii HDZ“, wspieranej przez część środowiska wojskowego. Spór groził naruszeniem równowagi politycznej w rządzie i strukturach partyjnych HDZ, dlatego przerwano prace nad kontrowersyjną ustawą ${ }^{24}$. Drugie podejście do opracowania strategii bezpieczeństwa narodowego nastapiło w 2012 roku, po wyborach, które wygrała koalicja partii centrolewicowych (Kukuriku koalicija). Nowa komisja została powołana pod koniec stycznia. Nadzór nad nią powierzono ministerstwu spraw zagranicznych i europejskich, sądząc, że osłabi to naciski polityczne na prace ekspertów. Rozwiązanie to nie przyniosło jednak oczekiwanych efektów. W 2012 roku komisja nie dotrzymała kilku terminów przedstawienia projektu strategii (pierwszy wyznaczono na 15 marca). W grudniu 2012 roku ministerstwo ogłosiło skierowanie projektu do konsultacji społecznych, które jednak utknęły w martwym punkcie. Tymczasem w sierpniu 2013 roku Sabor przyjął nowe ustawy o obronie i o służbie wojskowej, w których ani słowem nie wspomiano o przygotowanej strategii bezpieczeństwa narodowego. Dodajmy, że w chorwackim ustawodawstwie nie przewidziano przepisów, nakładających na władze obowiązek przyjęcia nowego dokumentu w określonym terminie ${ }^{25}$.

Problemy dotyczące adaptacji strategii bezpieczeństwa Republiki Chorwacji do zmienionych konfiguracji międzynarodowych w jakich to państwo się znalazło pokazują że proces formułowania jednolitej wykładni polityki bezpieczeństwa napotyka bariery. Najpoważniejszym problemem wydaje się być zróżnicowana optyka środowisk politycznych i wojskowych wobec interesów i podstawowych celów strategicznych państwa. O ile najważniejsze orientacje polityczne niezmiennie akcentują priorytetowe znaczenie członkostwa Chorwacji w strukturach euroatlantyckich, tak istnieje rozwarstwienie poglądów, w jakim zakresie państwo to powinno uczestniczyć w działaniach na rzecz stabilizacji politycznej i militarnej regionu. Ponadto należy postawić pytanie, czy stopniowa reforma polityki bezpieczeństwa w Chorwacji, w dużej mierze dyktowana względami międzynarodowymi, zostanie uznana za nieodwracalną i czy na trwale zmieni ona system odniesień wewnętrznych w administracji, instytucjach państwowych oraz społeczeństwie. W pierwszej połowie lat dziewięćdziesiątych społeczeństwo chorwackie odbierało oddziaływania z Zachodu pozytyw-

${ }^{23}$ Strategija nacjonalne sigurnosti protiv novih prijetnji, „Vjesnik”, 24 XII 2010, s. 2. Božinović: dnevnoj politici nije mjesto u Strategiji nacjonalne sigurnosti, „Vjesnik”, 12 I 2011, s. 5.

${ }^{24}$ I. Pokaz, Sigurnost vlastite zemlje najvazžija zadaća - temeljni pojmovi, „Hrvatski vojnik”, nr 428, 16 VIII 2013, s. 16.

25 Zakon o obrani (18 VI 2013); Zakon o službi u Oružanim snagama Republike Hrvatske (18 VI 2013), „Narodne novine”, 73/2013. 
nie, jako wspierające proces utrzymania państwowości i obrony przez agresją serbską. W taki sposób traktowano zarówno obecność międzynarodowych sił pokojowych na terenach ogarniętych konfliktem zbrojnym, jak i doradczą działalność zachodnich ekspertów. Pozytywny stosunek do wpływów zewnętrznych, mających stabilizować stosunki w rejonie postjugosłowiańskim słabł jednak pod wpływem międzynarodowej krytyki zaangażowania Chorwacji w konflikt bośniacki czy frustracji wywołanej traktatami potwierdzającymi integralność terytorialną Bośni, które przekreśliły chorwacką irredentę. Nasilająca się w drugiej połowie dekady międzynarodowa krytyka reżimu Franja Tudjmana pogłębiła opór wielu Chorwatów wobec mieszania się „,zagranicy" w sprawy wewnętrzne państwa. Nastroje te wykorzystywały niektóre partie polityczne, które swoje poparcie społeczne budowały na hasłach konsolidacji społeczeństwa w obliczu działan wymierzonych rzekomo w interesy narodowe Chorwatów. Przystapienie Chorwacji do Partnerstwa dla Pokoju i procesu stabilizacji i stowarzyszenia przyczyniło się do osłabienia wpływu przekazu nacjonalistycznego na życie publiczne, choć sytuację bezpieczeństwa Chorwacji komplikowały kontrowersje graniczne ze Słowenią czy kwestie odpowiedzialności karnej osób chorwackiego pochodzenia za zbrodnie wojenne, rozstrzygane zagranica przez Międzynarodowy Trybunał do spraw Byłej Jugosławii. To, że przed Chorwacją stawiano, podczas rozmów z UE twarde warunki członkostwa utwierdziło w społeczeństwie przekonanie, umacniane przez prawicowe środowiska polityczne, że szybka integracja ze strukturami euroatlantyckimi mogła narazić na szwank chorwacką pozycję wobec otoczenia międzynarodowego ${ }^{26}$. Istnieje obawa, że internalizacja rozwiązań przejmowanych przez państwo i społeczeństwo chorwackie z zewnątrz w związku z redefinicją zasad polityki bezpieczeństwa narodowego, może być na dalszym etapie hamowana przez samych obywateli w obawie przed nadmiernym osłabieniem dotychczasowego ładu społeczno-politycznego opartego na silnym wśród Chorwatów poczuciu dumy narodowej. Kontekst polityczny i kulturowy, w ramach którego prowadzona jest reforma sektora bezpieczeństwa Chorwacji nie sprzyja utwierdzaniu jej rezultatów w strukturach państwowych i społecznych. Dochodzi to tego brak zaufania obywateli wobec elit politycznych, z pewnością pogłębiany przez skutki kryzysu ekonomicznego. O ile w latach dziewięćdziesiątych na drodze do reformy sposobu postrzegania bezpieczeństwa narodowego w Chorwacji stały głównie względy polityczne, związane z władzą środowisk o zapędach autorytarnych, tak obecne wątpliwości dotyczą sukcesywnie zmniejszającego się przyzwolenia społecznego na dalsze zmiany, idące w kierunku większego zaangażowania się państwa w system współpracy międzynarodowej ${ }^{27}$.

Chorwacki kontekst prawny, w ramach którego rozwija się polityka bezpieczeństwa narodowego Chorwacji ewoluował w ciągu ostatnich dwudziestu lat, doświad-

${ }^{26}$ Por. N. Zambelli, A Journey westward: a poststructuralist analysis of Croatia's identity and the problem of cooperation with the International Criminal Tribunal for the Former Yugoslavia, „EuropeAsia studies", t. LXII, 2010, nr 10, s. 1671.

27 Por. M. Ogorec, Novi oblici ugroza i nacionalna sigurnost u percepciji hrvatskih građana, „Društvena istraživanja”, t. XVIII, 2009, nr 3, s. 347. 
czając wzlotów i upadków. Z pewnością polityka bezpieczeństwa znalazła się centrum działań zmierzających do przemeblowania systemu podstawowych wartości politycznych państwa na jego drodze do NATO i UE. Od 2000 roku państwo to dokonało dużego skoku w kierunku przezwyciężenia dekady formalnej demokracji, która stanowiła fasadę dla niedemokratycznych działań władz. Filarami ówczesnej polityki bezpieczeństwa były osoby nierzadko wywodzące się z establishmentu polityczno-wojskowego z czasów socjalistycznej Jugosławii. Jednym z podstawowych niedostatków obecnej polityki bezpieczeństwa Chorwacji jest brak procedur, które umożliwiłyby dostosowywanie istniejących dokumentów strategicznych do zmieniających się sytuacji społecznej, politycznej i ekonomicznej państwa. Problemy w pracach nad nową strategią bezpieczeństwa narodowego uwidaczniają, że transformacja poglądów na temat bezpieczeństwa państwa jest w toku. Na dyskurs polityczny w sposób negatywny nadal wpływają doświadczenia wojny z lat dziewięćdziesiątych i elity polityczne, uwikłane $\mathrm{w}$ dylemat, jak pogodzić tradycyjnie pojęty interes narodowy z imperatywem kooperacji międzynarodowej.

\title{
THE MAIN DETERMINANTS OF CROATIAN NATIONAL SECURITY POLICY DURING THE 1995-2013 PERIOD
}

\begin{abstract}
Summary
The article investigates the factors which determined the evolution of the national security concept in the Republic of Croatia during the period 1995-2013, as viewed by the political elite as well as the Croatian society. The Croatian public discourse approaches the national security in the context of either a multi-faceted reform of the country's security sector or an improvement of both the democratic control over the military and security forces. Among the former Yugoslav republics, Croatia accomplished major goals in its pursuit of the national security policy. After a period of arduous reforms and reconstruction, the country has become a member of both the NATO and the European Union. The issues which are still disputed among the researchers are the legal bases for the security policy and the process of the internalization of values lying at the foundation of the security sector reform. It is questionable whether or not the newly established system of legal and institutional references is likely to consolidate in the social, political and economic reality of modern Croatia.
\end{abstract}


